\title{
Matrix metalloproteinases (MMPs) and tissue inhibitors of MMPs in the respiratory tract: Potential implications in asthma and other lung diseases
}

\author{
Maud M. Gueders, Jean-Michel Foidart, Agnès Noel, Didier D. Cataldo \\ Department of Pneumology and department of Biology of Tumours and Development, Center for Biomedical Integrative Genoproteomics \\ (CBIG), Belgium University of Liege and Centre Hospitalier Universitaire de Liège (CHU-Liège), Belgium
}

\begin{abstract}
In healthy lung, Matrix Metalloproteinases (MMPs) and their physiological inhibitors, tissue inhibitors of matrix metalloproteinases (TIMPs), are produced in the respiratory tract by a panel of different structural cells. These activities are mandatory for many physiological processes including development, wound healing and cell trafficking. Deregulation of proteolytic-antiproteolytic network and inappropriate secretion of various MMPs by stimulated structural or inflammatory cells is thought to take part to pathophysiology of numerous lung diseases including asthma, chronic obstructive pulmonary disease (COPD), lung fibrosis and lung cancer. Cytokines and growth factors are involved in these inflammatory processes and some of those mediators interact directly with MMPs and TIMPs leading either to a regulation of their expression or changes in their biological activities by proteolytic cleavage. In turn, cytokines and growth factors modulate secretion of MMPs establishing a complex network of reciprocal interactions. Every MMP seem to play a rather specific role and some variations of their expression are observed in different lung diseases. The precise role of these enzymes and their inhibitors is now studied in depth as they could represent relevant therapeutic targets for many diseases. Indeed, MMP inhibition can lead either to a decrease of the intensity of a pathological process or, in the contrary for some of them, to an increase of disease severity. In this review, we focus on the role played by MMPs and TIMPs in asthma and we provide an overview of their potential roles in COPD, lung fibrosis and lung cancer, with a special emphasis on loops including MMPs and cytokines and growth factors relevant in these diseases.
\end{abstract}

Keywords: Matrix metalloproteinase; Tissue inhibitor of MMP; Asthma; Cytokine; Growth factors

\section{Matrix metalloproteinases (MMPs) and tissue inhibitors of metalloproteinases (TIMPs)}

Matrix metalloproteinases (MMPs), or matrixins, belong to the metzincin superfamily of metalloproteinases, also including astacins, ADAMs (a protein with a disintegrin and metallopro-tease domain) and ADAM-TS proteases (ADAM with a thrombospondin-like motif) (Sternlicht and Werb, 2001; Folgueras et al., 2004; Handsley and Edwards, 2005; Noel et al., 2004). MMPs are proteolytic enzymes believed to be implicated in many physiological and pathological processes including embryonic development, morphogenesis, reproductive processes, bone remodeling, wound healing, cancer, arthritis, atherosclerosis, MMPs are zinc and calciumdependent enzymes being able to degrade virtually all extracellular matrix components. This can modulate cell behaviour by creating influential cellular environment (Shapiro, 1998). The extracellular matrix is a complex network of molecules including collagens, fibronectin, laminin, entactin/ nidogen and heparan sulfate proteoglycans (Mott and Werb, 2004). The extracellular matrix is a mechanical support for cells but also acts as a reservoir for cytokines and growth factors (vascular endothelial growth factor (VEGF), transforming growth factor- $\beta$ (TGF- $\beta), \ldots)$. MMPs, by their proteolytic activity, can, on one hand, affect the adherence of cells to the extracellular matrix and, on the other hand, release both bioactive fragments of extracellular matrix molecules and "trapped" bioactive mediators, providing signals from the mic-roenvironment to cells allowing them to react to stimuli (Mott and Werb, 2004). For example, Laminin-5A, a component of basement membrane, is released from matrix by proteolytic activity of some MMPs (especially by MT1-MMP and MMP-2 activity) (Gilles et al., 2001). It was shown that $\gamma-2$ chain of laminin-5 induces epithelial cell migration allowing MMP activity to participate in the regulation of epithelial cell behaviour. In this context, MMPs also play important positive or negative roles in angiogenesis by different mechanisms. MMP-9 has been for instance reported to be essential for the mobilization of VEGF from the extracellular matrix (Handsley and Edwards, 2005). MMP-2 and MMP-9 promote angiogenesis by exposure of a cryptic epitope within collagen IV. In contrast, MMP-7 has the ability to generate anti-angiogenic factors by the release of endostatin fragments from the extracellular matrix. 
Since their first description by Gross and Lapière (1962), 28 MMPs have been described and 24 MMPs have been identified in vertebrates (Table 1). MMPs taxonomy was first built according to their substrate specificity but another classification of MMPs based on their structural similarities was proposed by Egeblad and Werb (2002). MMPs are indeed made of different domains and most are secreted from cells as latent pro-enzymes requiring the cleavage of an amino-terminal domain of approximately $10 \mathrm{kDa}$ (propeptide domain) to be activated. The precise mechanisms implicated in vivo in such an activation is still unknown but plasminogen/plasmin system is probably involved (Nagase, 1997). There are many structural differences among members of MMP family, participating in many cases in the fine tuning of proteolytic properties (substrates, activities,...) and in the regulation of protease-matrix interactions (adhesion, substrate selectivity). All MMPs share a pro-domain which contain in some cases a furin cleavage site allowing intracellular activation (MMP-11, MMP-21, MMP-23, MMP-28, MT-MMPs). In gelatinase subfamily of MMPs (MMP-2 and MMP-9), the catalytic domain that includes the $\mathrm{Zn}^{2+}$ binding site also contains repeats of fibronectin motifs allowing the ability to bind gelatin, their major substrate. Other domains shared by most MMPs are a proline-rich hinge region, a haemopexin-like domain responsible for most of substrate specificity and binding to specific inhibitors and, at least, a carboxy-terminal domain (Murphy and Willenbrock, 1995; Murphy and Knauper, 1997).

Membrane-type MMPs (MT-MMPs) represents a subclass of MMPs that are anchored to the plasma membrane by an additional specific transmembrane domain (Sounni and Noel, 2005; Zucker et al., 2003).

MMP synthesis and functions are regulated by three major mechanisms including transcriptional activation, post-transcrip-tional processing (release of pro-domain, cell surface shedding), and control of activity by a family of endogenous inhibitors collectively known as tissue inhibitors of metalloproteinases (TIMPs). Cytokines and growth factors, which display a rather complex relationship with MMPs as described in another section of this review, can act directly on the modulation of MMP gene expression (Lopez-Otin and Overall, 2002). As an example, tumor necrosis factor- $\alpha$ (TNF- $\alpha$ ) or interleukin-1 $\beta$ (IL-1 $\beta$ ) are able to induce induction of MMPs gene in tumours while TGF- $\beta$ is rather known to be a repressor of the expression of MMPs genes. As mentioned above, MMPs are secreted in a latent form and need to be activated by proteolysis. This conversion of pro-MMP into activated form can be performed in vitro by reactive oxygen radicals or physical conditions like $\mathrm{pH}$ or temperature (Nagase, 1997). In vivo, MMP activation involves other MMPs or serine proteases (Noel et al., 2004). For instance, activation of proMMP-2 is performed by membrane bound membrane type-1 MMP (MT1-MMP) (Lewalle et al., 1995; Zucker et al., 2003). Another level of control for MMP activity is their inhibition by endogenous inhibitors like TIMPs and $\alpha_{2}$-macroglobulin. This latter is mainly present in the fluid phase of plasma while TIMPs are considered to be key inhibitors in tissues. To date, four TIMPs (TIMP-1 to TIMP-4) have been identified in vertebrates. TIMPs are composed of a N-terminal and a C-terminal domain stabilized by disulfide bounds. As for MMPs, TIMP expression in tissues is tightly regulated to maintain an equilibrium between proteolysis and proteolysis inhibition leading extracellular matrix as a stable medium maintaining plastic capacities. Deregulation of TIMPs or MMPs activities leads to states of either exaggerated extracellular matrix turnover often leading to remodelling via impaired repair and scar formation or extracellular matrix accumulation leading to fibrosis. The four TIMPs have different affinity for the different MMPs (Brew et al., 2000). TIMP-1, TIMP-2, TIMP-4 are secreted proteins whereas TIMP-3 is anchored in extracellular matrix (Baker et al., 2002). TIMPs inhibit MMPs in a 1:1 stoechiometric and reversible manner.

TIMP-1 and TIMP-2 are able to make complexes with active forms of MMP-2 or MMP-9, and with the latent form of MMP-9 and MMP-2, respectively. TIMP-2 promotes an effective activation of proMMP-2 by formation of a ternary complex with MT1-MMP at cell surface. On the contrary, an excess of TIMP-2 inhibited proMMP-2 activation (Strongin et al., 1995; Seiki et al., 2003).

Many cell types have been identified as producers of MMPs and TIMPs in the lung. These enzymes and their inhibitors are produced by structural cells of the bronchial tree and alveolae and by inflammatory cells upon stimulation. In healthy lung, fibroblasts produce constitutively MMP-2, but are also a cellular source for MMP-1 and TIMP-1. Bronchial epithelial cells release MMP-2, MMP-9 and their major inhibitor, TIMP-1. In addition to these latter, alveolar epithelial cells and particularly type II pneumocytes, produce TIMP-2 and MMP-1 (Xu et al., 2002). Smooth muscle cells produce MMP-2 which controls their proliferation (Johnson and Knox, 1999). Smooth muscle cells are also a source of MT1 -MMP, TIMP-1 and TIMP-2 and produce MMP-3 and MMP-7 mRNA in moderate levels (Elshaw et al., 2004). Among inflammatory cells, neutrophils produce MMP-9, MMP8 and TIMP-1 which are synthesized and released from their secondary granules upon activation (Cataldo et al., 2001). Alveolar macrophages produce MMP-1, MMP-9, MMP-12 and TIMP-1. Mast cells play a key role in inflammatory processes occurring in the bronchial wall and, once activated by lymphocytes, produce at least MMP-9 (Baram et al., 2001). 
In pathological conditions, the activity and secretion profile of these cells can be modified, switching the expression and activity of MMPs and TIMPs and rendering this enzyme and their inhibitors implicated in many lung diseases as described below (Ohbayashi, 2002).

Table 1: the matrix metalloproteinase family

\begin{tabular}{|c|c|c|}
\hline Name & $\begin{array}{l}\text { Molecular weight } \\
\text { latent/active (kDa) }\end{array}$ & Substrates \\
\hline \multicolumn{3}{|l|}{ Interstitial collagenases } \\
\hline MMP-1 (collagenase-1) & $52 / 41$ & $\begin{array}{l}\text { Collagen I, II, II, VII, VIII, X, aggrecan, gelatin, pro- } \\
\text { MMP-2, pro-MMP-9 }\end{array}$ \\
\hline MMP-8 (collagenase-2) & $85 / 64$ & Collagen I, II, III, VII, VIII, X, aggrecan, gelatin \\
\hline MMP-13 (collagenase-3) & $65 / 55$ & Collagen I, II, III, aggrecan, gelatin \\
\hline MMP-18 (collagenase-4) & $53 / 42$ & \\
\hline \multicolumn{3}{|l|}{ Gelatinases } \\
\hline MMP-2 (Gelatinase-A) & $72 / 66$ & $\begin{array}{l}\text { Collagen I, II, III, IV, V, VII, X, XI, XIV, gelatin, elastin, } \\
\text { fibronectin, aggrecan }\end{array}$ \\
\hline MMP-9 (Gelatinase-B) & $92 / 85$ & $\begin{array}{l}\text { Collagen IV, V, VII, X, XIV, gelatin, pro-MMP-9, pro- } \\
\text { MMP-13, elastin, aggrecan }\end{array}$ \\
\hline \multicolumn{3}{|l|}{ Stromelysins } \\
\hline MMP-3 (Stromelysin-1) & $57 / 45,28$ & $\begin{array}{l}\text { Collagen II, III, IV, IX, X, XI, elastin, pro-MMP-1, pro- } \\
\text { MMP-7, pro-MMP-8, pro-MMP-9, pro-MMP-13 }\end{array}$ \\
\hline MMP-10 (Stromelysin-2) & $56 / 47,24$ & Collagen III, IV, V, gelatin, fibronectin \\
\hline MMP-11 (Stromelysin-3) & $58 / 28$ & Fibronectin, laminin, gelatin, aggrecan \\
\hline \multicolumn{3}{|l|}{ Membrane-type MMPs } \\
\hline MMP-14 (MT1-MMP) & $66 / 60$ & $\begin{array}{l}\text { Pro-MMP-2, pro-MMP-13, collagen I, II, III, gelatin, } \\
\text { aggrecan, fibronectin, laminin }\end{array}$ \\
\hline MMP-15 (MT2-MMP) & $68 / 62$ & Pro-MMP-2, gelatin, fibronectin, laminin \\
\hline MMP-16 (MT3-MMP) & $64 / 55$ & Pro-MMP-2 \\
\hline MMP-17 (MT4-MMP) & $57 / 53$ & Unknown \\
\hline MMP-24 (MT5-MMP) & $63 / 45$ & Pro-MMP-2 \\
\hline MMP-25 (MT6-MMP) & Unknown & Gelatin \\
\hline \multicolumn{3}{|l|}{ Others } \\
\hline MMP-7 (matrilysin-2) & $28 / 19$ & $\begin{array}{l}\text { Collagen II, III, IV, IX, X, XI, elastin, pro-MMP-1, pro- } \\
\text { MMP-7, pro-MMP-8, pro-MMP-9, pro-MMP-13, gelatin, } \\
\text { aggrecan, fibronectin, laminin }\end{array}$ \\
\hline MMP-26 (matrilysin) & 28/unknown & Collagen IV, gelatin, fibronectin \\
\hline MMP-12 (metalloelastase) & $54 / 45,22$ & Elastin \\
\hline MMP-19 & $57 / 45$ & Tenascin, gelatin, aggrecan \\
\hline MMP-20 (enamelysin) & $54 / 22$ & Enamel, gelatin \\
\hline MMP-21 & $70 / 53$ & Unknown \\
\hline MMP-23 & Unknown & Unknown \\
\hline MMP-27 & Unknown & Unknown \\
\hline MMP-28 (epilysin) & Unknown/58, 55 & Unknown \\
\hline
\end{tabular}

\section{Implication of MMPs in the pathogenesis of asthma}

Bronchial asthma is a pulmonary disorder characterized by the development of bronchial hyperresponsiveness, chronic persistent infiltration of the airway wall by inflammatory cells, and airways structural changes referred to as "bronchial remodeling". This latter probably leads to an increased rate of lung function decrease during the life (Lange et al., 1998). The main structural changes described in bronchi of asthmatics are: (a) an epithelial thickening and a sub-epithelial fibrosis mainly linked to deposition of different collagen subtypes (types I and III) and fibronectin, (b) some changes of extracellular matrix composition (e.g., elastic fibres fragmentation, 
tenascin deposition,...), (c) smooth muscle cell hyperplasia, (d) mucus-producing cells ("Goblet cells") hyperplasia, (e) increase in the surface of blood vessels in airway walls, and (f) perichondral fibrosis (Bousquet et al., 1992; Cataldo et al., 2003; Vignola et al., 1998a).

MMP-9 was the first MMP to be studied in depth for its implication in pathology of asthma. Increased levels of MMP-9 were indeed detected in bronchoalveolar lavage fluid (Mautino et al., 1997), sputum induced by the inhalation of hypertonic saline (Cataldo et al., 2000; Vignola et al., 1998b) and in serum of asthmatic patients (Bosse et al., 1999). The increased MMP-9 activity observed in the airways of asthmatic patients seems related to an increased number of granulocytes and more precisely neutrophils in the airways rather than to an enhancement of MMP-9 secretion by those cells (Cataldo et al., 2001; Prause et al., 2004). Other authors have suggested that eosinophils, key cells in asthma-related airway inflammation, could also be a major source for MMP-9 in this disease (Ohno et al., 1997). A significant correlation was indeed found in immunohistochemistry and in situ hybridisation between MMP-9 expression and eosinophil counts in bronchial mucosa. MMP-9 is also expressed by bronchial epithelium and may be an important factor promoting eosinophilic infiltration into the airways from patients suffering from asthma (Han et al., 2003; Ohno et al., 1997). Although the interest of investigating a balance between MMP-9 and TIMP-1 would probably be restricted to the pericellular area, some authors have reported an imbalance observed between MMP-9 and TIMP-1 measured in bronchial secretions or bronchoalveolar lavage, with a significant increase of TIMP-1 production when compared to that of MMP-9, thought to favouring extracellular matrix deposition (Mautino et al., 1999; Vignola et al., 1998b). However, other authors studying such fluids (bronchoalveolar lavage or induced sputum) or bronchial wall did not report such an imbalance suggesting that bronchial inflammation would lead to a proteolytic burden followed by scar formation resulting in a disorganised extracellular matrix (Cataldo et al., 2002a; Hoshino et al., 1999; Kelly et al., 2000). Moreover, in asthmatics, TIMP-1 was reported to be secreted in a lesser extent by granulocytes suggesting that it could exist an imbalance between proteolytic and anti-proteolytic activities at the pericellular level in the airway wall (Cataldo et al., 2002a; Hoshino et al., 1999; Kelly et al., 2000).

MMP-9 levels were increased after allergen challenge in the sputum from allergic asthmatics as compared to control subjects and correlated to the percentage of eosinophils while TIMP-1 levels did not vary significantly (Cataldo et al., 2002a; Kelly et al., 2000). This observation suggests that extracellular matrix can be aggressed after allergen contact and are linked to allergen-induced acute bronchial inflammation. A significant correlation was observed between MMP-9 levels and both the maximum percent fall in forced expiratory volume at the first second $\left(\mathrm{FEV}_{1}\right)$ during the late response and the number of neutrophils in sputum (Boulay et al., 2004).

Severity of asthma is also a factor influencing protease secretion in airways. MMP-9 levels in sputum from patients with severe asthma, particularly those with nonreversible airway obstruction, are even higher when compared to patients with mild asthma (Mattos et al., 2002). In this context of severe disease, MMP-9 serum levels were also increased when compared to milder asthmatics (Belleguic et al., 2002). Therefore, MMP-9 level measurements could be proposed as a useful tool to determine one of the aspects of disease severity.

Regulation of MMP-9 secretion in airways appears complex since both inflammatory and structural cells are able to produce that protease. On epithelial cell surface, protease-sensitive receptors can be found such as proteinaseactivated receptor-2 (PAR-2) which is activated mainly by serine proteases, such as trypsin and mast cell tryptase, and induce the release of MMP-9 by airway epithelial cells suggesting that these receptors could be implicated in tissue remodelling occurring in asthma (Vliagoftis et al., 2000). Besides MMP-9 release, PAR-2mediated activation of airway epithelial cells also induces release of granulocyte macrophage colony stimulating factor (GM-CSF) and eotaxin, which promotes eosinophil survival and activation, as well as recruitment of these inflammatory cells to airways, respectively (Vliagoftis et al., 2000). In vivo, intranasal stimulation of mice with IL-17, known to promote neutrophil recruitment, induced the release of proMMP-9 and active MMP-9 in bronchoalveolar lavage fluid, associated with a pronounced local accumulation of neutrophils displaying a positive staining for MMP-9 (Prause et al., 2004). In mouse models of asthma, the absence of MMP-9 is responsible for a decrease of infiltration of airways and bronchoalveolar lavage by inflammatory cells. MMP-9 knock-out (KO) mice failed to develop allergen-induced airway hyperresponsiveness (Cataldo et al., 2002b). MMP-9 gene deletion seems to be effective on allergen-induced inflammatory process by decreasing dendritic cell trafficking, which is one of the key events during initiation of allergic immune responses including asthma (Vermaelen et al., 2003). Interestingly, another study using also MMP-9 KO mice reported that MMP-9 is not essential for leukocyte migration and that MMP-9 deletion could promote both airway inflammation and hyperresponsiveness (McMillan et al., 2004). The difference between those two last studies can be ascribed to a significant difference in allergen exposure protocol, the latter study being performed with a 5 time higher antigen concentration. 
Neutrophils play a significant role in asthma as soon as the disease becomes severe (ENFUMOSA study group, 2003). Besides MMP-9 production, neutrophils also produce MMP-8 that is stored in their secondary granules and released upon stimulation. An increase of MMP-8 expression has been reported in bronchial biopsies and in bronchoalveolar lavage from asthmatic patients suggesting that this enzyme could play an important role in this disease (Cataldo et al., 2001; Prikk et al., 2002). To verify this hypothesis, we recently applied a mouse model of asthma to MMP-8 deficient mice (MMP-8 KO) and we found surprisingly that mice lacking MMP-8 displayed a severe granulocytic inflammation in airways after allergen exposure (Gueders et al., 2005). In this model, neutrophil apoptosis was lower in MMP-8 KO mice after allergen exposure indicating a probable role for MMP8 in regulation of processes leading to neutrophil clearance.

In addition to their potential role in airway inflammation described here, MMPs are also thought to play a significant role in tissue remodeling process. Inflammatory cells such as T cells, eosinophils and mast cells but also some structural cells such as smooth muscle cells are believed to cause irreversible airway structural changes by both MMP secretion and production of pro-inflammatory cytokines or growth factors that can be either activated or inactivated by proteolytic cleavage resulting from the activity of MMPs. For instance, deposition of collagen I, III and fibronectin in the reticular layer of basement membrane is thought to be caused by cycles of matrix degradation and impaired repair and could be favoured by an overproduction of activated TGF- $\beta$. This process involves probably at least MMP-2 and MMP-9 which share the ability to disrupt normal basement membrane. MMP-1, secreted by hyperplastic smooth muscle cells may play a role in hyperplasia of these latter, probably by activating insulin-like growth factor (IGFs) axis (Rajah et al., 1999). IGF-1 is indeed produced by airway epithelial cells and is a potent growth factor for airway smooth muscle cells proliferation perhaps by its ability to up-regulate MMP-2, a well recognized smooth muscle cell mitogen, at several levels (Zhang et al., 2004). In normal conditions, in humans, MMP-2 is secreted by airway smooth muscle cells and is effective on cell proliferation in an autocrine manner. Increased airway smooth muscle mass is perhaps the most important component of the airway wall remodeling process in asthma (Hirst and Twort, 1992). Inhibition of MMP-2 significantly reduces smooth muscle cells proliferation (Johnson and Knox, 1999).

The picture is rendered even more complex when considering the interplay of different protease-antiprotease systems including plasminogen/plasmin system. Two plasminogen activators (urokinase-type plasminogen activator and tissue plasminogen activator (uPA and tPA)) convert plasminogen into plasmin (Noel et al., 2004). The main physiological inhibitor of plasminogen activators (plasminogen activator inhibitor-1 (PAI)-1) is known to regulate the adhesion and migration of a variety of cells during the inflammatory response (Blasi, 1999; Noel et al., 2004) and is thought to interact with MMP system in the lung. Indeed, PAI-1 is mainly produced by mast cells and may promote extracellular matrix deposition, at least by inhibiting MMP-9 activity (Cho et al., 2004). This afford the demonstration of the role played by PAI-1 in extracellular matrix homeostasis since those mice displayed less collagen and fibrin deposition in airway wall and higher MMP-9 activity (Oh et al., 2002).

\subsection{Interactions between MMPs and cytokines - growth factors in asthma}

Complex interactions occur between MMPs, TIMPs, cytokines and growth factors. In asthma, inflammation is driven by a specific subclass of $\mathrm{T}$ lymphocytes referred to as $\mathrm{Th}_{2}$ lymphocytes that orchestrate and perpetuate inflammation and remodeling through secretion of specific cytokines, mainly interleukin-4 (IL-4), IL-5, IL-9, and IL-13 (Renauld, 2001), playing distinct roles. IL-4 is the major factor regulating IgE production by B cells, and is required for optimal $\mathrm{Th}_{2}$ differentiation. Regarding the key role of cytokines in allergen-induced inflammatory processes, anti-cytokines therapies have been investigated in asthma. These studies revealed that blocking IL-4 is not sufficient to inhibit asthma development in experimental animal models. In contrast, inhibition of IL-13, another $\mathrm{Th}_{2}$ cytokine whose signal transduction pathway overlaps with that of IL-4, completely blocks airway hyperreactivity, subepithelial fibrosis and progression of inflammation in mouse asthma models. These effects were associated with an inhibition of MMP-9, neutralisation of IL-13 resulting in a reduction in total proteins MMP-9 levels in the lung tissue of mice (Yang et al., 2005).

Some $\mathrm{Th}_{2}$ cytokines contribute in a significant manner to pathology of asthma and other lung inflammatory diseases by interacting directly with MMPs or TIMPs resulting in an increase or decrease of their expression and activity. IL-4 decreased MMP-2 protein and mRNA levels in human bronchial fibroblasts in culture but did not alter TIMP-2 production leading to an increased TIMP-2/MMP-2 ratio. In addition, IL-4 positively regulates procollagen I transcription by direct promoter activation thereby supporting the profibrotic effect of this cytokine. Based on these observations, IL-4 might be considered as a potential link between inflammation and collagen deposition observed in asthmatic airways (Bergeron et al., 2003). It has been described that MMP inhibitors administered intratracheally in a mouse model of asthma can exert a direct effect on cytokines and are able to significantly abrogate the increased expression of cytokines, including IL-4 mRNA in lung tissues and 


\section{IL-4 levels in bronchoalveolar lavage fluids (Lee et al., 2004).}

IL-5 is another major $\mathrm{Th}_{2}$ cytokine exerting an effect on eosinophils production, maturation, activation and acting as a strong chemotactic agent for those cells (Chung and Barnes, 1999). This cytokine could therefore significantly contribute to tissue damages observed in chronic asthma. IL-5 levels are increased in the bronchoalveolar lavage fluid of patients with symptomatic asthma. T cells, eosinophils and mast cells express IL-5 mRNA and secrete this cytokine. Eosinophils are known to express mainly MMP-9 but the influence of IL5 on this production is not yet demonstrated. Indeed, culture of peripheral blood eosinophils, in presence of IL-5, did not induce MMP-9 production after 4 days (Fujisawa et al., 1999). However, anti-IL-5 therapy markedly reduced peripheral blood and airway eosinophils and remodelling (decreased expression of tenascin and procollagen III, and decrease of the thickness of reticular basement membrane), but does not appear to be really effective on symptoms of asthmatic patients (Flood-Page et al., 2003). As some of these benefits might be linked to a specific interaction of IL-5 inhibition with members of the MMP family, some further studies should elucidate this particular point.

IL-13 is thought to interact directly with many MMPs and TIMPs. In the lung, IL-13 is considered as a central regulator of allergic asthma by its contribution to the regulation of eosinophilic inflammation, subepithelial fibrosis, mucus hypersecretion and airway hyperresponsiveness. IL-13 is a pleiotropic cytokine that either directly or indirectly affects the function of multiple cell types, including T cells, eosinophils, mast cells, basophils, epithelial cells, smooth muscle cells, fibroblasts and macrophages in many pathological conditions like inflammatory diseases of the lung or cancer (Kuperman et al., 2002). Exaggerated production of IL-13 has been documented in a variety of diseases characterized by inflammation and remodeling including asthma. IL-13 has a direct effect on immune cells and is sufficient and necessary for the induction and the maintenance of allergen-induced activation of dendritic cells (Grunig et al., 2005). In a murine model of tobacco-induced lung damage, it has been described that IL-13 overexpression induces MMP-2, MMP-9, MMP-12, MMP-13, MMP14 expression (Zheng et al., 2000). Blocking MMPs in this model led to a significant decrease of IL-13-induced emphysema. IL-13-related effects such as alveolar enlargement and respiratory failure are especially mediated by MMP-9 and MMP-12-dependent pathways. MMP-9 inhibits rather neutrophils accumulation while MMP-12 plays an inhibitory role on the eosinophils and macrophages accumulation (Lanone et al., 2002). In this picture, MMP-9 and MMP-12 could then be considered as downstream mediators and regulators of IL-13-induced inflammatory response. It has been described that IL-13 alone has no effect on TIMP-1 expression (Zhou et al., $2005)$. However, in the presence of TGF- $\beta 1$, IL-13 synergistically augments TIMP-1 mRNA, at a transcriptional level, and protein expression in human airway fibroblasts. TGF- $\beta$ is a pro-fibrotic cytokine involved in remodeling and particularly in the formation of subepithelial fibrosis and levels of TGF- $\beta$ are correlated with the thickness of basement membrane (Sagara et al., 2002). TGF- $\beta$ is secreted by macrophages, fibroblasts, epithelial cells, smooth muscle cells but also by inflammatory cells including eosinophils, neutrophils and mast cells (Chung and Barnes, 1999). In normal conditions, TGF- $\beta 1$ is present in the lower respiratory tract and mainly in bronchial epithelium. TGF- $\beta$ levels measured in bronchial biopsies from asthmatics were elevated as compared to control subjects (Vignola et al., 1997). Loops of reciprocal control exist between TGF- $\beta$ and MMPs since MMP-9 activates latent TGF- $\beta$, these latter, once activated acts directly on MMP-9 expression and plays a pivotal role increasing its production and secretion in a mouse model of remodeling (Ohbayashi, 2002; Santibanez et al., 2002).

Other cytokines also display more or less complex interactions with members of the MMP family. Monocyte chemoat-tractant protein-1 (MCP-1) contributes undoubtfully to extracellular matrix changes observed during airway remodeling by increasing the mRNA for MMP-1 and TIMP-1 expression in cells from the bronchial secretions in asthmatics (Cataldo et al., 2002a). IL-1 $\beta$, a pro-inflammatory cytokine, is increased in lungs of patients with asthma and is converted from its latent form by different proteases including MMP-9 (Schonbeck et al., 1998). Production of biologically active IL-1 $\beta$ expression in lungs of adult mice causes pulmonary inflammation characterized by neutrophil and macrophage infiltration. IL-1 $\beta$ has also been reported to contribute to fibrosis in airway walls increasing the thickness of conducting airway walls, and to enhance mucus production. These effects of IL- $1 \beta$ could be explained by its ability to increase the production of the neutrophil attractant CXC chemokines "cytokine-induced neutrophil chemoattractant" referred to as "KC" (CXCL1) and macrophage inflammatory protein-2 (MIP-2) (CXCL2), and the levels of matrix metalloproteinases MMP-9 and MMP-12 (Lappalainen et al., 2005).

Relationship between the production of MMP-2 and the insulin-like growth factors (IGF) was previously discussed. Other growth factors as fibroblast growth factor (FGF), which is found associated with extracellular matrix, can have direct effect on MMPs production by fibroblasts. Indeed FGF-1, in presence of heparin which strongly enhances its effect, induces a marked upregulation of MMP-1 secretion in fibroblasts that do not express 
the enzyme at the basal level (Becerril et al., 1999). On the contrary, the constitutive production of TIMP-1 and TIMP-2 by human lung fibroblasts in vitro is not significantly modulated by stimulation by FGF alone or FGF in combination with heparin. Platelet derived growth factor (PDGF) is released from very different cells in airways including airway epithelial cells, fibroblasts, endothelial cells, macrophages and smooth muscle cells. The release of PDGF by fibroblasts and by endothelial cells can be induced by TNF- $\alpha$, TGF- $\beta$, IL-1 $\beta$, hypoxia and FGF. PDGF could be a key actor of bronchial remodelling in asthma in that it stimulates lung fibroblast proliferation. PDGF also stimulates fibroblasts chemotaxis and MMP-1 production by those cells. This stimulation is increased by combining PDGF with IL-1 $\beta$ and TNF- $\alpha$. IL1- $\beta$ and TNF- $\alpha$ display inhibitory effects on MMP-2 and MMP-9 production. PDGF, in combination with IL-1 $\beta$ and TNF- $\alpha$, induced MMP-3 and MMP-9 activity. These findings suggest that PDGF differentially regulated MMP production in combination with cytokines.

\subsection{New therapeutic insights in asthma}

Based on the observation of increased levels of MMPs in asthmatic patients and taking into account the potential risk of side effects of broad spectrum inhibitors of metalloproteinases that have led to the discontinuation of most clinical trials in the field of cancer (Folgueras et al., 2004), the need for studying specific roles played by individual MMPs appears obvious. This was performed in many cases using MMP deficient mice (MMP-2, -8, 9 and -12). Results of gene deletion for MMP- 8 and -9 were discussed above. The application of a model of allergic asthma on MMP-2-deficient mice, revealed that MMP-2 deletion causes inflammatory cell infiltration of alveolae and a decrease of inflammatory cells recovered in bronchoalveolar lavage despite a strong peribronchovascular cell accumulation (Cony et al., 2002). These observations suggest that MMP-2 plays a role in the luminal clearance of inflammatory cells. MMP-12 Knock-Out mice were also investigated and the main finding was a decrease in most of inflammatory cells after allergen exposure as compared to the wild-type mice (Warner et al., 2004).

Inhaled corticosteroid treatment is the mainstay of asthma therapy as soon as the disease reaches the mild persistent severity step (GINA Guidelines, 1995). This class of drugs could have a curative effect on remodeling by reducing subepithelial collagen deposition, probably by downregulation of MMP-9 expression and upregulation of TIMP-1 expression (Hoshino et al., 1999). This observation was however not confirmed by other authors. In sputum cells studied ex vivo, steroids reduced both MMP-9 and TIMP-1 production (Profita et al., 2004). MMPs could represent an interesting therapeutic target in asthma since some reports indicate the validity of a MMP inhibition-based approach for asthma therapy in animal models. Indeed, airway inflammation and hyperresponsiveness were shown to be reduced by administration of recombinant TIMP-2 in the bronchial tree (Kumagai et al., 1999). TIMP-2 appears to be effective in preventing extracellular matrix damages at least in part by inhibition of MMP-2 and related proteolytic activity (Kumagai et al., 2002). The effect of doxycycline (a broad-spectrum MMP inhibitor) and other synthetic non-specific inhibitors on bronchial inflammation and airway hyperresponsiveness was evaluated by the use of a murine model for TDI-induced asthma. After oral administration of doxycycline, mice display a decreased airway inflammation, airway hyperresponsiveness, and a decreased expression of MMP-9 at mRNA and protein levels (Lee et al., 2001, 2004). Other in vitro studies suggest that non-specific MMP inhibition by GM-6001 could lead to a decrease of goblet cell hyperplasia, one of the components of airway remodeling in asthma (Yoshisue and Hasegawa, 2004).

Taken together, these data identify MMPs as potential therapeutic targets in asthma. One would expect that a nonspecific MMP inhibition would lead to some adverse events since the deletion of some of the MMP family aggravates the allergen-induced inflammation as a direct consequence. However, the first few trials in vitro and in vivo on animal models were performed with some inhibitors known for their nonspecific effect on MMP activity and seem to control adequately allergen-induced inflammation without obvious side effects. Should a specific MMP inhibitor be selected, it seems logical in view of the current literature to target MMP-9 in priority. It seems also logical to avoid a systemic inhibition of collage-nases, responsible for most of the osteo-articular side effects (Wojtowicz-Praga et al., 1998).

\section{Potential roles of MMPs in other pulmonary diseases}

\subsection{Chronic obstructive pulmonary disease (COPD)}

The incidence of chronic obstructive pulmonary disease (COPD) is increasing worldwide and is ranked as the fourth most common cause of death in the United States. COPD is caused by long-term exposure to cigarette smoke, toxic gases, and particulate matter, leading to airflow limitation and pulmonary failure. The disease is characterized by an excess of extracellular matrix deposition in bronchial walls, chronic cough, sputum 
production and destruction of alveolar septa, resulting in reduced functional lung parenchyma and reduced elastic tethering forces that maintain airways open. Like asthma, COPD is characterized by airway flow obstruction and a chronic persistent inflammatory process but these diseases are very different in terms of cellular mechanisms, nature of inflammation and response to therapy (Jeffery, 2001). Approximately 10\% of COPD patients also have asthma and COPD is often managed in clinical practice as poorly responsive asthma (Barnes, 2000). The development of extensive tissue remodelling in COPD causes destruction of small bronchi and alveolae, leading to emphysema and involves many members of the MMP family.

Matrix metalloproteinases have been suggested from recent studies as the major proteolytic enzymes involved in the pathogenesis of COPD. Increased levels of MMP-1 and MMP-9 have been detected in bronchoalveolar lavage fluid of patients with emphysema (Finlay et al., 1997b). As compared with healthy subjects, patients with COPD have a marked increase in expression and activity of MMP-2, MMP-9 and MT1-MMP in their lung parenchyma (Ohnishi et al., 1998) and increased gelatinolytic activity linked to MMP-2 and MMP-9 in their sputum (Cataldo et al., 2000; Vignola et al., 1998b). In bronchoalveolar lavage fluid of smokers with emphysema, an increase of collagenolytic activity, probably due to elevated levels of MMP-8, is measured when compared to smokers without emphysema (Betsuyaku et al., 1999) indicating that injury to the collagen network of the lung is also a part of the disease. When studied ex vivo, alveolar macrophages from patients with emphysema express more MMP-1 and MMP-9 than macrophages from healthy subjects suggesting that macrophages are the main cellular source of MMP-1 and MMP-9 in COPD (Finlay et al., 1997a). As it has a potent elastolytic activity, MMP-12 is thought to play a determinant role in development of COPD and emphysema. Experimental data show that mice exposed to cigarette smoke express more MMP-12 mRNA than non-exposed mice (Bracke et al., 2005). MMP-12 gene deletion in mice protects from the development of emphysema after long term exposure to cigarette smoke (Hautamaki et al., 1997). Alveolar macrophages were considered to be the unique source of MMP-12 (macrophage metalloelastase). Recently, it was demonstrated that MMP-12 is also expressed and secreted by normal human bronchial epithelial cell cultures (Lavigne et al., 2004). These findings indicate that bronchial epithelium may be an important source of elastolytic activity in COPD. Taken together, these elements suggest that MMP-12 could be seriously considered as a potential target for COPD treatment (Nenan et al., 2005). Indeed, some reports establish the potential interest for a MMP inhibition-based approach in COPD, based on results obtained in animal models. Orally bioavailable synthetic MMP inhibitors were showed to decrease the rapidity of alveolar destruction in murine and Guinea Pig models of tobacco smoke exposure (Martin et al., 2001).

\subsection{Lung fibrosis}

Pulmonary fibrosis is a severe chronic disease characterized by a loss of lung epithelial cells, replaced by interstitial myofibroblasts and deposition of extracellular matrix proteins in the lung interstitium leading to pulmonary structural remodeling (Crouch, 1990). Idiopathic pulmonary fibrosis (IPF) is a chronic, usually fatal, disorder characterized by excessive matrix degradation and interstitial and intraalveolar fibrosis leading to dyspnea, impaired oxygen transfer and alveolar collapse (Katzenstein and Myers, 1998). The defects in the alveolar epithelium and basement membrane allow the migration of mesenchymal cells from the interstitium into the intraluminal compartment. Intraluminal fibrosis is one of the major characteristics of IPF and is associated with recruitment of inflammatory cells, particularly, macrophages, neutrophils and lymphocytes in the airways leading to an imbalance between the synthesis and degradation of extracellular matrix molecules in the local lung environment (Morimoto et al., 2005; Selman et al., 2000).

In lung fibrosis, a temporal difference is observed in expression and localisation of MMPs and TIMPs (Swiderski et al., 1998; Yaguchi et al., 1998). In the early stage of this disease, gelatinolytic activity of MMP-9 seems predominant and probably contributes to disruption of alveolar epithelial basement membrane, and enhances fibroblast invasion to alveolar spaces. MMP-9 and MMP-1 are released by infiltrating neutrophils, macrophages, bronchial and bronchiolar epithelial cells. In vivo, it was shown that gelatinase B (MMP-9) expression is increased in cultured alveolar macrophages and in bronchoalveolar lavage fluid from patients suffering from idiopathic pulmonary fibrosis. In vitro, MMP-9 expression in cultured alveolar macrophages is decreased by a treatment with steroids and immunosuppressive agents. In the late stages of the disease, MMP-2 (in latent and active forms) seems to become predominant. MMP-2 is localized in structural cells like regenerated alveolar epithelial, bronchial epithelial cells and fibroblasts. In lung fibrosis, MMP-2 could play a role in the regeneration of alveolar epithelial cells (Fukuda et al., 1998; Lemjabbar et al., 1999; Manoury et al., 2005; Scabilloni et al., 2005). The expression of the two gelatinases (MMP-2 and MMP-9) at different stages of fibrosis suggests that MMP-9 could be rather linked to inflammation-induced tissue remodeling, while MMP-2 may be associated with an impaired tissue remodeling leading to pathological collagen deposition and interstitial fibrosis. 
Besides the implication of gelatinases, MMP-7 is identified as a potential target for therapy of patients with IPF as MMP-7 gene is detected to be overexpressed by micro-array gene analysis (Cosgrove et al., 2002). Indeed, MMP-7 deficiency (MMP-7 KO mice) is shown to hamper the experimental pulmonary fibrosis in a mouse model (Zuo et al., 2002). As far as collagen accumulation is a mainstay of lung fibrosis, the downregulation of collagenases, which share the ability to cleave the native helix of fibrillar collagens, could also play a significant role in disease progression. Indeed, a decreased expression of MMP-8 and MMP-13 have been described in a rat model of lung fibrosis (Ruiz et al., 2003). In line with this observation, there is an overexpression of TIMPs leading to an imbalance between MMPs and their inhibitors resulting in a micro environment unfavourable to collagenolytic activity (Selman et al., 2000). TIMP-1, TIMP-2 and TIMP-3 are produced by different cells and have distinct roles in MMPs activity regulation. TIMP-2 is mainly localized in regenerated epithelial cells and in fibroblasts (Fukuda et al., 1998). TIMP-1 was primarily expressed on alveolar macrophages and epithelial cells. TIMP-2 and TIMP-3 genes were constitutively expressed whereas TIMP-1 gene expression is up-regulated during fibrosis. TIMP-1 expression is correlated with stages of disease progression and may prevent MMPinduced extracellular matrix degradation, and, as a consequence, may participate in the accumulation of extracellular matrix. MMP detection could be proposed as a prognosis factor in lung fibrosis as described for MMP-9 (Lemjabbar et al., 1999).

In the perspective of re-establishing the protease/antipro-teases homeostasis, some different approaches could be considered. First, antiprotease therapy has been proposed in lung fibrosis in the hope to control the disease extension and to have a preventive effect. Corbel et al. showed that bleomycin-induced pulmonary fibrosis was prevented by the administration of the MMP-inhibitor batimastat (Corbel et al., 2002). Alternatively, it could be considered that an hypothetical therapeutic intervention that would allow the MMP activity to control the collagen accumulation by tight regulation of TIMP activity should be experimented as a curative approach of the disease.

\subsection{Role of MMPs in lung cancer}

By their ability to disrupt the extracellular matrix allowing cell migration and release of bioactive molecules, MMPs contribute to the formation of a complex micro environment that promotes malignant transformation and cancer progression (Folgueras et al., 2004; Handsley and Edwards, 2005; Sounni and Noel, 2005). MMPs take part to the processes leading to metastasis to distant sites. Many experimental data are now available about the expression of different MMPs in cancer and we can cite here only a few of them.

MMP-9 and TIMP-1 are elevated in the serum of patients with both Small Cell Lung Cancer (SCLC) and NonSmall Cell Lung Cancer (NSCLC), when compared to healthy subjects modifying the natural physiological relationship between MMP-9 and TIMP-1 (Jumper et al., 2004).

In NSCLC, MMP-1 and gelatinases (MMP-2 and MMP-9) contribute to tumor invasion and metastasis and have been proposed as reliable prognostic factors (Reichenberger et al., 2001). Overexpression of MMP-1 is associated with a particularly poor prognosis in lung carcinoma as described for other cancer types (Kodate et al., 1997). The destruction of basement membrane (type IV collagen) or MMP-2 expression correlated with the prognosis of invasive lung adenocarcinomas (Pritchard et al., 2001). Elevated levels of MT1-MMP are also linked to a poor prognosis (Tokuraku et al., 1995). MMP expression could also vary in function of cancer subtypes. MMP-11, MMP-13, MMP-14, TIMP-2 and TIMP-3 are indeed more frequently expressed than MMP1 and MMP-9 and the role played by some of these enzymes appears to be different in SCLC and NSCLC (Michael et al., 1999). Strong MMP-2 expression in stromal fibroblasts was more frequently seen in squamous cell carcinoma than in adenocarcinoma, two different types of NSCLC. MMP-2 could play a role in tumourrelated angiogenesis since tumours with strong MMP-2 expression in stromal fibroblasts showed a significantly higher intratumoral microvessel density. Moreover, combined overexpression of VEGF and MMP-2 is associated with a poor prognosis (Shou et al., 2001). In addition, postoperative prognosis was linked to stromal MMP-2. MMP-2 expression by tumour stroma fibroblasts could thus be considered as a good prognostic factor associated with angiogenesis and survival in NSCLC (Ishikawa et al., 2004). Elevated levels of plasma MMP-9 were observed in patients with NSCLC but the role of MMP-9 as a marker of lung cancer is still unclear. In NSCLC, MMP-9 seems to play a role in the process leading to metastasis development. Metastatic dissemination was hampered in MMP-9-deficient mice when compared to wild-type control mice in a mouse model of cancer dissemination (Itoh et al., 1999). The expression of TIMPs (particularly TIMP-1 and TIMP-2) was correlated with the cancer stage (Thomas et al., 2000) and their levels have been proposed to be used as prognosis markers of lung adenocarcinoma progression (Ylisirnio et al., 2000). 


\subsection{Antiprotease therapy in cancer}

The first generation of MMP inhibitors, used in cancer therapy, were not successful and most of clinical trials were aborted in early stages. This is probably due to the complex role of MMPs and TIMPs, being involved in multiple loops of reciprocal interaction in physiological and pathological conditions (Folgueras et al., 2004) and to the toxicity of systemic MMP inhibition. Different broad spectrum MMP inhibitors like Batimastat (BB94) or Prinomastat failed at phase I and III of clinical trials, respectively and development of several other MMP inhibitors was stopped due to their systemic toxicity and poor efficacy (Hoekstra et al., 2001). As synthetic MMP inhibitors are rather toxic, one could address the use of TIMPs. TIMPs used as MMP inhibitors in different diseases have revealed some paradoxical effects. For example, TIMP-4 up-regulates anti-apoptotic protein Bcl-X, thereby stimulating mammary tumourigenesis (Jiang et al., 2001). TIMPs (and synthetic inhibitors) may also block the activity of MMPs that are not necessarily overexpressed in tumour or play protective roles against cancer such as MMP-8 for instance (Balbin et al., 2003). These observations highlight the need for developing new strategies of MMP inhibition. Different strategies could be investigated. First, generation of new synthetic MMP inhibitors that inhibit individual MMPs would allow a control of specific processes related to tumour progression. However, this approach is still hypothetical since MMPs share many structural features with an active site very conserved among members of this proteases class. Another approach would be a targeting one, allowing MMP inhibitor delivery at the tumour site thereby allowing the use of high local therapeutic concentrations and a decrease of systemic toxicity. For lung cancer, aerosol administration could also be considered since it would increase the therapeutic index and allow higher concentration in the target organ. To the best of our knowledge, no clinical trials have been conducted to date using such a strategy.

\section{Conclusion}

In conclusion, MMPs and their inhibitors (TIMPs) play multiple functions in physiological processes and interact with many other mediators regulating inflammatory processes, cell behaviour, and angiogenesis,... These mediators are implicated in many intricate loops of reciprocal interactions rendering the understanding of the role of MMPs in regulatory processes difficult. In many diseases, MMPs are overexpressed or oversecreted leading to both deregulation of physiological homeostatic processes and extracellular matrix degradation and disorganisation.

\section{Acknowledgements}

This work was supported by grants of the Fonds National de la Recherche Scientifique (FNRS, Brussels, Belgium), the Walloon Region Government (DGTRE), the Fondation Leon Fredericq (University of Liege), the CHU (Liege, Belgium), Action de Recherches Concertées (00/05-264, Communauté Française de Belgique), European Union (FP6, LSH-CT-2003-503297). Dr CATALDO is a Scientific Research Worker of the Fonds National de la Recherche Scientifique (FNRS-Belgium).

\section{References}

Baker, A.H., Edwards, D.R., Murphy, G., 2002. Metalloproteinase inhibitors: biological actions and therapeutic opportunities. J. Cell Sci. 115,3719-3727.

Balbin, M., Fueyo, A., Tester, A.M., Pendas, A.M., Pitiot, A.S., Astudillo, A, Overall, CM., Shapiro, S.D., Lopez-Otin, C, 2003. Loss of collagenase-2 confers increased skin tumor susceptibility to male mice. Nat. Genet. 35, 252-257.

Baram, D., Vaday, G.G., Salamon, P., Drucker, I., Hershkoviz, R., Mekori, Y.A., 2001. Human mast cells release metalloproteinase-9 on contact with activated T cells: juxtacrine regulation by TNF-alpha. J. Immunol. 167, 4008-4016.

Barnes, P.J., 2000. Mechanisms in COPD — differences from asthma. Chest 117, 10-14.

Becerril, C, Pardo, A., Montano, M., Ramos, C, Ramirez, R., Selman, M., 1999. Acidic fibroblast growth factor induces an antifibrogenic phenotype in human lung fibroblasts. Am. J. Respir. Cell Mol. Biol. 20, 1020-1027.

Belleguic, C., Corbel, M., Germain, N, Lena, H., Boichot, E., Delaval, P.H., Lagente, V., 2002. Increased release of matrix metalloproteinase-9 in the plasma of acute severe asthmatic patients. Clin. Exp. Allergy 32, 217-223.

Bergeron, C., Page, N., Joubert, P., Barbeau, B., Hamid, Q., Chakir, J., 2003. Regulation of procollagen I (alpha 1) by interleukin-4 in human bronchial fibroblasts: a possible role in airway remodelling in asthma. Clin. Exp. Allergy 33, 1389-1397. 
Betsuyaku, T., Nishimura, M., Takeyabu, K., Tanino, M., Venge, P., Xu, S.Y., Kawakami, Y., 1999. Neutrophil granule proteins in BAL fluid from subjects with subclinical emphysema. Am. J. Respir. Crit. Care Med. 159, A193.

Blasi, F., 1999. Proteolysis, cell adhesion, chemotaxis, and invasiveness are regulated by the u-PA-u-PAR-PAI-1 system. Thromb. Haemost. 82, 298-304.

Bosse, M., Chakir, J., Rouabhia, M., Boulet, L.P., Audette, M., Laviolette, M., 1999. Serum matrix metalloproteinase-9: tissue inhibitor of metalloproteinase-1 ratio correlates with steroid responsiveness in moderate to severe asthma. Am. J. Respir. Crit. Care Med. 159, 596-602.

Boulay, M.E., Prince, P., Deschesnes, F., Chakir, J., Boulet, L.P., 2004. Metalloproteinase-9 in induced sputum correlates with the severity of the late allergen-induced asthmatic response. Respiration 71, 216-224.

Bousquet, J., Chanez, P., Lacoste, J.Y., White, R., Vic, P., Godard, P., Michel, F.B., 1992. Asthma - a disease remodeling the airways. Allergy 47, 3-11.

Bracke, Ken, Cataldo, D., Maes, T., Gueders, M., Noel, A., Foidart, J.M., Brusselle, G., Pauwels, R., 2005. Matrix metalloproteinase-12 expression in pulmonary dendritic cells of cigarette smoke exposed mice. Int. Arch. All. Immunol. 138 (2), $169-179$.

Brew, K., Dinakarpandian, D., Nagase, H., 2000. Tissue inhibitors of metalloproteinases: evolution, structure and function. Biochim. Biophys. Acta Prot. Struct. Mol. Enzymol. 1477, 267-283.

Cataldo, D., Munaut, C, Noel, A., Frankenne, F., Bartsch, P., Foidart, J.M., Louis, R., 2000. MMP-2-and MMP-9-linked gelatinolytic activity in the sputum from patients with asthma and chronic obstructive pulmonary disease. Int. Arch. Allergy Immunol. 123, $259-267$.

Cataldo, D., Munaut, C, Noel, A., Frankenne, F., Bartsch, P., Foidart, J.M., Louis, R., 2001. Matrix metalloproteinases and TIMP-1 production by peripheral blood granulocytes from COPD patients and asthmatics. Allergy 56, 145-151.

Cataldo, D., Gueders, M., Noel, A., Foidart, J.M., Bartsch, P., Louis, R., 2002a. Matrix metalloproteinases (MMPs) and tissue inhibitors of matrix metalloproteinases (TIMPs) mRNA transcripts in the bronchial secretions of asthmatics and COPD. Lab. Invest. 84, 418-424.

Cataldo, D.D., Tournoy, K.G., Vermaelen, K., Munaut, C, Foidart, J.M., Louis, R., Noel, A., Pauwels, R.A., 2002b. Matrix metalloproteinase-9 deficiency impairs cellular infiltration and bronchial hyperresponsiveness during allergen-induced airway inflammation. Am. J. Pathol. 161, 491-498.

Cataldo, D.D., Gueders, M.M., Rocks, N, Sounni, N.E., Evrard, B., Bartsch, P., Louis, R., Noel, A., Foidart, J.M., 2003. Pathogenic role of matrix metalloproteases and their inhibitors in asthma and chronic obstructive pulmonary disease and therapeutic relevance of matrix metalloproteases inhibitors. Cell. Mol. Biol. 49, 875-884.

Cho, S.H., Ryu, C.H., Oh, C.K., 2004. Plasminogen activator inhibitor-1 in the pathogenesis of asthma. Exp. Biol. Med. 229, $138-146$.

Chung, K.F., Barnes, P.J., 1999. Cytokines in asthma. Thorax 54, 825-857.

Corbel, M., Belleguic, C, Boichot, E., Lagente, V., 2002. Involvement of gelatinases (MMP-2 and MMP-9) in the development of airway inflammation and pulmonary fibrosis. Cell Biol. Toxicol. 18, 51-61.

Corry, D.B., Rishi, K., Kanellis, J., Kiss, A., Song, L.Z., Xu, J., Feng, L.L., Werb, Z., Kheradmand, F., 2002. Decreased allergic lung inflammatory cell egression and increased susceptibility to asphyxiation in MMP2-deficiency. Nat. Immunol. 3, $347-353$.

Cosgrove, G.P., Schwarz, M.I., Geraci, M.W., Brown, K.K., Worthen, G.S., 2002. Overexpression of matrix metalloproteinase-7 in pulmonary fibrosis. Chest $121,25 \mathrm{~S}-26 \mathrm{~S}$.

Crouch, E., 1990. Pathobiology of pulmonary fibrosis. Am. J. Physiol. 259, L159-L184.

Egeblad, M., Werb, Z., 2002. New functions for the matrix metalloproteinases in cancer progression. Nat. Rev., Cancer 2, $161-174$.

Elshaw, S.R., Henderson, N, Knox, A.J., Watson, S.A., Buttle, D.J., Johnson, S.R., 2004. Matrix metalloproteinase expression and activity in human airway smooth muscle cells. Br. J. Pharmacol. 142, 1318-1324.

ENFUMOSA group, 2003. The ENFUMOSA cross-sectional European multicentre study of the clinical phenotype of chronic severe asthma, European Network for Understanding Mechanisms of Severe Asthma. Eur. Respir. J. 22, 470-477.

Finlay, G.A., ODriscoll, L.R., Russell, K.J., Darcy, E.M., Masterson, J.B., Fitzgerald, M.X., OConnor, C.M., 1997a. Matrix metalloproteinase expression and production by alveolar macrophages in emphysema. Am. J. Respir. Crit. Care Med. 156, $240-247$.

Finlay, G.A, Russell, K.J., McMahon, K.J., Darcy, E.M., Masterson, J.B., FitzGerald, M.Z., OConnor, CM., 1997b. Elevated levels of matrix metalloproteinases in bronchoalveolar lavage fluid of emphysematous patients. Thorax 52, 502-506. 
Flood-Page, P., Menzies-Gow, A., Phipps, S., Ying, S., Wangoo, A., Ludwig, M.S., Barnes, N, Robinson, D., Kay, A.B., 2003. Anti-IL-5 treatment reduces deposition of ECM proteins in the bronchial subepithelial basement membrane of mild atopic asthmatics. J. Clin. Invest. $112,1029-1036$

Folgueras, A.R., Pendas, A.M., Sanchez, L.M., Lopez-Otin, C, 2004. Matrix metalloproteinases in cancer: from new functions to improved inhibition strategies. Int. J. Dev. Biol. 48, 411-424.

Fujisawa, T, Kato, Y., Terada, A., Iguchi, K, Kamiya, H., 1999. Matrix metalloproteinase-9 in peripheral blood eosinophils. Int. Arch. Allergy Immunol. 120, 65-69.

Fukuda, Y., Ishizaki, M., Kudoh, S., Kitaichi, M., Yamanaka, N., 1998. Localization of matrix metalloproteinases-1,-2, and -9 and tissue inhibitor of metalloproteinase-2 in interstitial lung diseases. Lab. Invest. 78, 687-698.

Gilles, C, Polette, M., Coraux, C, Tournier, J.M., Meneguzzi, G., Munaut, C., Volders, L., Rousselle, P., Birembaut, P., Foidart, J.M., 2001. Contribution of MT1-MMP and of human laminin-5 gamma 2 chain degradation to mammary epithelial cell migration. J. Cell Sci. 114, $2967-2976$

Global Initiative for Asthma (GINA). Global strategy for asthma management and prevention. NIH Publication 02-3659 issued January 1995 (Updated 2004).

Gross, J., Lapière, CM., 1962. Collagenolytic activity in amphibian tissues: a tissue culture assay. Proc. Natl. Acad. Sci. U S. A. 48, 10141022.

Grunig, G., Padilla, J., Daley, E., Robinson, K, Donaldson, D.D., 2005. IL-13 controls the immune response to inhaled antigens. FASEB J. 19, A939.

Gueders, M.M., Balbin, M., Rocks, N., Foidart, J.M., Gosset, P., Louis, R., Shapiro, S.D., Lopez-Otin, C., Noel, A., Cataldo, D.D., 2005. Matrix metalloproteinase-8 deficiency promotes granulocytic allergen-induced airway inflammation. J. Immunol. 175, $2589-2597$.

Han, Z., Junxu, Zhong, N., 2003. Expression of matrix metalloproteinases MMP-9 within the airways in asthma. Resp. Med. 97, 563-567.

Handsley, M.M., Edwards, D.R., 2005. Metalloproteinases and their inhibitors in tumor angiogenesis. Int. J. Cancer 115, 849-860.

Hautamaki, R.D., Kobayashi, D.K., Senior, R.M., Shapiro, S.D., 1997. Requirement for macrophage elastase for cigarette smoke-induced emphysema in mice. Science 277, 2002-2004.

Hirst, S.J., Twort, C.H.C, 1992. The proliferative response of airway smooth-muscle. Clin. Exp. Allergy 22, $907-915$.

Hoekstra, R., Eskens, F.A.L.M., Verweij, J., 2001. Matrix metalloproteinase inhibitors: current developments and future perspectives. Oncologist 6, 415-427.

Hoshino, M., Takahashi, M., Takai, Y, Sim, J., 1999. Inhaled corticosteroids decrease subepithelial collagen deposition by modulation of the balance between matrix metalloproteinase-9 and tissue inhibitor of metalloprotei-nase-1 expression in asthma. J. Allergy Clin. Immunol. 104, 356-363.

Ishikawa, S., Takenaka, K., Yanagihara, K., Miyahara, R., Kawano, Y., Otake, Y., Hasegawa, S., Wada, H., Tanaka, F., 2004. Matrix metalloproteinase-2 status in stromal fibroblasts, not in tumor cells, is a significant prognostic factor in non-small-cell lung cancer. Clin. Cancer Res. 10, 6579-6585.

Itoh, T., Tanioka, M., Matsuda, H., Nishimoto, H., Yoshioka, T, Suzuki, R., Uehira, M., 1999. Experimental metastasis is suppressed in MMP-9-deficient mice. Clin. Exp. Metastasis 17, 177-181.

Jeffery, P.K., 2001. Remodeling in asthma and chronic obstructive lung disease. Am. J. Respir. Crit. Care Med. 164, S28-S38.

Jiang, Y.F., Wang, M.S., Celiker, M.Y, Liu, Y.E., Sang, Q.X.A., Goldberg, I.D., Shi, Y.E., 2001. Stimulation of mammary tumorigenesis by systemic tissue inhibitor of matrix metalloproteinase 4 gene delivery. Cancer Res. 61, 2365-2370.

Johnson, S., Knox, A., 1999. Autocrine production of matrix metalloproteinase-2 is required for human airway smooth muscle proliferation. Am. J. Physiol., Lung Cell. Mol. Physiol. 277, L1109-L1117.

Jumper, C., Cobos, E., Lox, C., 2004. Determination of the serum matrix metalloproteinase-9 (MMP-9) and tissue inhibitor of matrix metalloprotei-nase-1 (TIMP-1) in patients with either advanced small-cell lung cancer or non-small-cell lung cancer prior to treatment. Respir. Med. 98, 173-177.

Katzenstein, A.L.A., Myers, J.L., 1998. Idiopathic pulmonary fibrosis — clinical relevance of pathologic classification. Am. J. Respir. Crit. Care Med. 157, 1301-1315.

Kelly, E.A.B., Busse, W.W., Jarjour, N.N., 2000. Increased matrix metalloproteinase-9 in the airway after allergen challenge. Am. J. Respir. Crit. Care Med. 162, 1157-1161. 
Kodate, M., Kasai, T, Hashimoto, H., Yasumoto, K, Iwata, Y, Manabe, H., 1997. Expression of matrix metalloproteinase (gelatinase) in T1 adenocarcinoma of the lung. Pathol. Int. 47, 461-469.

Kumagai, K, Ohno, I., Okada, S., Ohkawara, Y., Suzuki, K., Masu, K., Shinya, T., Nagase, H., Iwata, K., Shirato, K., 1999. Inhibition of matrix metalloproteinases prevents allergen-induced airway inflammation in a murine model of asthma. Am. J. Respir. Crit. Care Med. 159, A325.

Kumagai, K., Ohno, I., Imai, K., Nawata, J., Hayashi, K., Okada, S., Senoo, H., Hattori, T., Shirato, K., 2002. The involvement of matrix metalloproteinases in basement membrane injury in a murine model of acute allergic airway inflammation. Clin. Exp. Allergy 32, 15271534.

Kuperman, D.A., Huang, X.Z., Koth, L.L., Chang, G.H., Dolganov, G.M., Zhu, Z., Elias, J.A., Sheppard, D., Erie, D J., 2002. Direct effects of interleukin-13 on epithelial cells cause airway hyperreactivity and mucus overproduction in asthma. Nat. Med. 8, 885-889.

Lange, P., Parner, J., Vestbo, J., Schnohr, P., Jensen, G., 1998. A 15-year follow-up study of ventilatory function in adults with asthma. N. Engl. J. Med. 339, 1194-1200.

Lanone, S., Zheng, T., Zhu, Z., Liu, W., Lee, C.G., Ma, B., Chen, Q.S., Homer, R.J., Wang, J.M., Rabach, L.A., Rabach, M.E., Shipley, J.M., Shapiro, S.D., Senior, R.M., Elias, J.A., 2002. Overlapping and enzyme-specific contributions of matrix metalloproteinases-9 and-12 in IL13-induced inflammation and remodeling. J. Clin. Invest. 110, 463-474.

Lappalainen, U., Whitsett, J.A., Wert, S.E., Tichelaar, J.W., Bry, K., 2005. Interleukin-1 beta causes pulmonary inflammation, emphysema, and airway remodeling in the adult murine lung. Am. J. Respir. Mol. Biol. 32, 311-318.

Lavigne, M.C., Thakker, P., Gunn, J., Wong, A., Miyashiro, J.S., Wasserman, A.M., Wei, S.Q., Pelker, J.W., Kobayashi, M., Eppihimer, M.J., 2004. Human bronchial epithelial cells express and secrete MMP-12. Biochem. Biophys. Res. Commun. 324, 534-546.

Lee, Y.C., Lee, H.B., Rhee, Y.K., Song, C.H., 2001. The involvement of matrix metalloproteinase-9 in airway inflammation of patients with acute asthma. Clin. Exp. Allergy 31, 1623-1630.

Lee, K.S., Jin, S.M., Kim, S.S., Lee, Y.C., 2004. Doxycycline reduces airway inflammation and hyperresponsiveness in a murine model of toluene diisocyanate-induced asthma. J. Allergy Clin. Immunol. 113, 902-909.

Lemjabbar, H., Gosset, P., Lechapt-Zalcman, E., Franco-Montoya, M.L., Wallaert, B., Harf, A., Lafuma, C., 1999. Overexpression of alveolar macrophage gelatinase B (MMP-9) in patients with idiopathic pulmonary fibrosis - effects of steroid and immunosuppressive treatment. Am. J. Respir. Cell Mol. Biol. 20, 903-913.

Lewalle, J.M., Munaut, C., Pichot, B., Cataldo, D., Baramova, E., Foidart, J.M., 1995. Plasma membrane-dependent activation of gelatinase A in human vascular endothelial-cells. J. Cell. Physiol. 165, 475-483.

Lopez-Otin, C., Overall, C.M., 2002. Protease degradomics: a new challenge for proteomics. Nat. Rev., Mol. Cell Biol. 3 , $509-519$.

Manoury, B., Nenan, S., Leclerc, O., Guenon, I., Boichot, E., Planquois, J.M., Bertrand, C.P., Lagente, V., 2005. The absence of reactive oxygen species production protects mice against bleomycin-induced pulmonary fibrosis. Respir. Res. 6, 11 .

Martin, R., Shapiro, S., Tong, S., Van Wart, H., 2001. Macrophage metalloelastase inhibitors. Prog. Respir. Res. (Karger, Basel) 31, 177180.

Mattos, W., Lim, S., Russell, R., Jatakanon, A., Chung, R., Barnes, P.J., 2002. Matrix metalloproteinase-9 expression in asthma — effect of asthma severity, allergen challenge, and inhaled corticosteroids. Chest 122, 1543-1552.

Mautino, G, Oliver, N, Chanez, P., Bousquet, J., Capony, F., 1997. Increased release of matrix metalloproteinase-9 in bronchoalveolar lavage fluid and by alveolar macrophages of asthmatics. Am. J. Respir. Cell Mol. Biol. 17, 583-591.

Mautino, G, Henriquet, C., Gougat, C., Le Cam, A., Dayer, J.M., Bousquet, J., Capony, F., 1999. Increased expression of tissue inhibitor of metalloprotei-nase-1 and loss of correlation with matrix metalloproteinase-9 by macrophages in asthma. Lab. Invest. $79,39-47$.

McMillan, S.J., Kearley, J., Campbell, J.D., Zhu, X.W., Larbi, K.Y., Shipley, J.M., Senior, R.M., Nourshargh, S., Lloyd, CM., 2004. Matrix metalloproteinase-9 deficiency results in enhanced allergen-induced airway inflammation. J. Immunol. 172, 2586-2594.

Michael, M., Babic, B., Khokha, R., Tsao, M., Ho, J., Pintilie, M., Leco, K., Chamberlain, D., Shepherd, F.A., 1999. Expression and prognostic significance of metalloproteinases and their tissue inhibitors in patients with small-cell lung cancer. J. Clin. Oncol. 17, $1802-1808$.

Morimoto, Y, Kim, H., Oyabu, T, Hirohashi, M., Nagatomo, H., Ogami, A., Yamato, H., Higashi, T, Tanaka, I., Kasai, T, 2005. Effect of long-term inhalation of toner on extracellular matrix in the lungs of rats in vivo. Inhal. Toxicol. 17, 153-159.

Mott, J.D., Werb, Z., 2004. Regulation of matrix biology by matrix metalloproteinases. Curr. Opin. Cell Biol. 16, 558-564. 
Murphy, G, Knauper, V., 1997. Relating matrix metalloproteinase structure to function: why the "hemopexin" domain? Matrix Biol. 15, 511518 .

Murphy, G, Willenbrock, F., 1995. Tissue inhibitors of matrix metalloendo-peptidases. Proteolytic Enzymes: Aspartic and Metallo Peptidases, vol. 248, pp. 496-510.

Nagase, H., 1997. Activation mechanisms of matrix metalloproteinases. Biol. Chem. 378, 151-160.

Nenan, S., Boichot, E., Lagente, V., Bertrand, C.P., 2005. Macrophage elastase (MMP-12): a pro-inflammatory mediator? Mem. Inst. Oswaldo Cruz 100, 167-172.

Noel, A., Maillard, C, Rocks, N, Jost, M., Chabottaux, V, Sounni, N.E., Maquoi, E., Cataldo, D., Foidart, J.M., 2004. Membrane associated proteases and their inhibitors in tumour angiogenesis. J. Clin. Pathol. 57, 577-584.

Oh, C.K., Ariue, B., Alban, R.F., Shaw, B., Cho, S.H., 2002. PAI-1 promotes extracellular matrix deposition in the airways of a murine asthma model. Biochem. Biophys. Res. Commun. 294, 1155-1160.

Ohbayashi, H., 2002. Matrix metalloproteinases in lung diseases. Curr. Protein Pept. Sci. 3, 409-421.

Ohnishi, K, Takagi, M., Kurokawa, Y, Satomi, S., Konttinen, Y.T., 1998. Matrix metalloproteinase-mediated extracellular matrix protein degradation in human pulmonary emphysema. Lab. Invest. 78, 1077-1087.

Ohno, I., Ohtani, H., Nitta, Y., Suzuki, J., Hoshi, H., Honma, M., Isoyama, S., Tanno, Y., Tamura, G., Yamauchi, K., Nagura, H., Shirato, K., 1997. Eosinophils as a source of matrix metalloproteinase-9 in asthmatic airway inflammation. Am. J. Respir. Cell Mol. Biol. 16, 212219.

Prause, O., Bozinovski, S., Anderson, G.P., Linden, A., 2004. Increased matrix metalloproteinase-9 concentration and activity after stimulation with interleukin-17 in mouse airways. Thorax 59, 313-317.

Prikk, K, Maisi, P., Pirila, E., Reintam, M.A., Salo, T, Sorsa, T., Sepper, R., 2002. Airway obstruction correlates with collagenase-2 (MMP8) expression and activation in bronchial asthma. Lab. Invest. 82, 1535-1545.

Pritchard, S.C., Nicolson, M.C., Lloret, C, Mckay, J.A., Ross, V.G., Kerr, K.M., Murray, G.I., Mcleod, H.L., 2001. Expression of matrix metalloproteinases 1, 2, 9 and their tissue inhibitors in stage II non-small cell lung cancer: implications for MMP inhibition therapy. Oncol. Rep. 8, 421-424.

Profita, M., Gagliardo, R., Di Giorgi, R., Bruno, A., Riccobono, L., Bonanno, A., Bousquet, J., Vignola, A.M., 2004. In vitro effects of flunisolide on MMP-9, TIMP-1, fibronectin, TGF-betal release and apoptosis in sputum cells freshly isolated from mild to moderate asthmatics. Allergy 59, 927-932.

Rajah, R., Nachajon, R.V., Collins, M.H., Hakonarson, H., Grunstein, M.M., Cohen, P., 1999. Elevated levels of the IGF-binding protein protease MMP-1 in asthmatic airway smooth muscle. Am. J. Respir. Crit. Care Med. 20, 199-208.

Reichenberger, F., Eickelberg, O., Wyser, C., Perruchoud, A.P., Roth, M., Tamm, M., 2001. Distinct endobronchial expression of matrixmetallopro-teinases (MMP) and their endogenous inhibitors in lung cancer. Swiss Med. Wkly. 131, 273-279.

Renauld, J.C., 2001. New insights into the role of cytokines in asthma. J. Clin. Pathol. 54, 577-589.

Ruiz, V., Ordonez, R.M., Berumen, J., Ramirez, R., Uhal, B., Becerril, C, Pardo, A., Selman, M., 2003. Unbalanced collagenases/TIMP-1 expression and epithelial apoptosis in experimental lung fibrosis. Am. J. Physiol., Lung Cell. Mol. Physiol. 285, L1026-L1036.

Sagara, H., Okada, T., Okumura, K., Ogawa, H., Ra, C., Fukuda, T, Nakao, A., 2002. Activation of TGF-beta/Smad2 signaling is associated with airway remodeling in asthma. J. Allergy Clin. Immunol. 110, 249-254.

Santibanez, J.F., Guerrero, J., Quintanilla, M., Fabra, A., Martinez, J., 2002. Transforming growth factor-betal modulates matrix metalloproteinase-9 production through the Ras/MAPK signaling pathway in transformed keratinocytes. Biochem. Biophys. Res. Commun. 296, 267-273.

Scabilloni, J.F., Wang, L.Y., Antonini, J.M., Roberts, J.R., Castranova, V., Mercer, R.R., 2005. Matrix metalloproteinase induction in fibrosis and fibrotic nodule formation due to silica inhalation. Am. J. Physiol., Lung Cell. Mol. Physiol. 288 , L709-L717.

Schonbeck, U., Mach, F., Libby, P., 1998. Generation of biologically active IL-1 beta by matrix metalloproteinases: a novel caspase-1independent pathway of IL-1 beta processing. J. Immunol. 161, 3340-3346.

Seiki, M., Koshikawa, N., Yana, I., 2003. Role of pericellular proteolysis by membrane-type 1 matrix metalloproteinase in cancer invasion and angio-genesis. Cancer Metastasis Rev. 22, 129-143.

Selman, M., Ruiz, V., Cabrera, S., Segura, L., Ramirez, R., Barrios, R., Pardo, A., 2000. TIMP-1,-2,-3, and-4 in idiopathic pulmonary fibrosis. A prevailing nondegradative lung microenvironment? Am. J. Physiol., Lung Cell. Mol. Physiol. 279 , L562-L574. 
Shapiro, S.D., 1998. Matrix metalloproteinase degradation of extracellular matrix: biological consequences. Curr. Opin. Cell Biol. 10, 602608 .

Shou, Y., Hirano, T., Gong, Y., Kato, Y., Yoshida, K., Ohira, T., Ikeda, N., Konaka, C., Ebihara, Y., Zhao, F., Kato, H., 2001. Influence of angiogenetic factors and matrix metalloproteinases upon tumour progression in non-small-cell lung cancer. Br. J. Cancer 85, $1706-1712$.

Sounni, N.E., Noel, A., 2005. Membrane type-matrix metalloproteinases and tumor progression. Biochimie 87, $329-342$.

Sternlicht, M.D., Werb, Z., 2001. How matrix metalloproteinases regulate cell behavior. Annu. Rev. Cell Dev. Biol. 17, 463-516.

Strongin, A.Y, Collier, I., Bannikov, G., Maimer, B.L., Grant, G.A., Goldberg, G.I., 1995. Mechanism of cell-surface activation of 72-Kda Type-Iv col-lagenase - isolation of the activated form of the membrane metallopro-tease. J. Biol. Chem. 270, 5331-5338.

Swiderski, R.E., Dencoff J.E., Floerchinger, C.S., Shapiro, S.D., Hunninghake, G.W., 1998. Differential expression of extracellular matrix remodeling genes in a murine model of bleomycin-induced pulmonary fibrosis. Am. J. Pathol. 152, 821-828.

Thomas, P., Khokha, R., Shepherd, F.A., Feld, R., Tsao, M.S., 2000. Differential expression of matrix metalloproteinases and their inhibitors in non-small cell lung cancer. J. Pathol. 190, 150-156.

Tokuraku, M., Sato, H., Murakami, S., Okada, Y., Watanabe, Y., Seiki, M., 1995. Activation of the precursor of gelatinase A/72 Kda TypeIv collagenase/ Mmp-2 in lung carcinomas correlates with the express ion of membrane-type matrix metallo proteinase (Mt-Mmp) and with lymph-node metastasis. Int. J. Cancer 64, 355-359.

Vermaelen, K.Y, Cataldo, D., Tournoy, K., Maes, T., Dhulst, A., Louis, R., Foidart, J.M., Noel, A., Pauwels, R., 2003. Matrix metalloproteinase-9-mediated dendritic cell recruitment into the airways is a critical step in a mouse model of asthma. J. Immunol. 171, 1016-1022.

Vignola, A.M., Chanez, P., Chiappara, G., Merendino, A., Pace, E., Rizzo, A., laRocca, A.M., Bellia, V., Bonsignore, G, Bousquet, J., 1997. Transforming growth factor-beta expression in mucosal biopsies in asthma and chronic bronchitis. Am. J. Respir. Crit. Care Med. 156, 591599.

Vignola, A.M., Chanez, P., Siena, L., Chiappara, G, Bonsignore, G., Bousquet, J., 1998a. Airways remodelling in asthma. Pulm. Pharmacol. Ther. 11, 359-367.

Vignola, A.M., Riccobono, L., Mirabella, A., Profita, M., Chanez, P., Bellia, V., Mautino, G., D'Accardi, P., Bousquet, J., Bonsignore, G., 1998b. Sputum metalloproteinase-9 tissue inhibitor of metalloproteinase-1 ratio correlates with airflow obstruction in asthma and chronic bronchitis. Am. J. Respir. Crit. Care Med. 158, 1945-1950.

Vliagoftis, H., Hollenberg, M.D., Befus, A.D., Moqbel, R., 2000. Airway epithelial cells release eosinophil survival promoting factors following stimulation of proteinase-activated receptor-2 (PAR-2). J. Allergy Clin. Immunol. 105, S171.

Warner, R.L., Lukacs, N.W., Shapiro, S.D., Bhagarvathula, N, Nerusu, K.C., Varani, J., Johnson, K.J., 2004. Role of metalloelastase in amodel of allergic lung responses induced by cockroach allergen. Am. J. Pathol. 165, 1921-1930.

Wojtowicz-Praga, S., Torri, J., Johnson, M., Steen, V., Marshall, J., Ness, E., Dickson, R., Sale, M., Rasmussen, H.S., Chiodo, TA., Hawkins, M.J., 1998. Phase I trial of marimastat, a novel matrix metalloproteinase inhibitor, administered orally to patients with advanced lung cancer. J. Clin. Oncol. 16, 2150-2156.

Xu, J., Benyon, R.C., Leir, S.H., Zhang, S., Holgate, S.T., Lackie, P.M., 2002. Matrix metalloproteinase-2 from bronchial epithelial cells induces the proliferation of subepithelial fibroblasts. Clin. Exp. Allergy 32, 881-888.

Yaguchi, T., Fukuda, Y., Ishizaki, M., Yamanaka, N., 1998. Immunohistochem-ical and gelatin zymography studies for matrix metalloproteinases in bleomycin-induced pulmonary fibrosis. Pathol. Int. 48, 954-963.

Yang, G.Y., Li, L., Volk, A., Emmell, E., Petley, T., Giles-Komar, J., Rafferty, P., Lakshminarayanan, M., Griswold, D.E., Bugelski, P.J., Das, A.M., 2005. Therapeutic dosing with anti-interleukin-13 monoclonal antibody inhibits asthma progression in mice. J. Pharmacol. Exp. Ther. 313, 8-15.

Ylisirnio, S., Hoyhtya, M., Turpeenniemi-Hujanen, T., 2000. Serum matrix metalloproteinases-2, -9 and tissue inhibitors of metalloproteinases-1, -2 in lung cancer - TIMP-1 as a prognostic marker. Anticancer Res. 20, 1311-1316.

Yoshisue, H., Hasegawa, K., 2004. Effect of MMP/ADAM inhibitors in goblet cell hyperplasia in cultured human bronchial epithelial cells. Biosci. Biotechnol. Biochem. 68, 2024-2031.

Zhang, D.L., Bar-Eli, M., Meloche, S., Brodt, P., 2004. Dual regulation of MMP-2 expression by the type 1 insulin-like growth factor receptor - the phosphatidylinositol 3-kinase/Akt and Raf/ERK pathways transmit opposing signals. J. Biol. Chem. 279, 19683-19690.

Zheng, T., Zhu, Z., Wang, Z.D., Homer, R.J., Ma, B., Riese, R.J., Chapman, H.A., Shapiro, S.D., Elias, J.A., 2000. Inducible targeting of IL13 to the adult lung causes matrix metalloproteinase- and cathepsin-dependent emphysema. J. Clin. Invest. 106, 1081-1093. 
Published in: European Journal of Pharmacology (2006), vol. 533, iss.1-3, pp. 133-144

Status: Postprint (Author's version)

Zhou, X.X., Trudeau, J.B., Schoonover, K.J., Lundin, J.I., Barnes, S.M., Cundall, M.J., Wenzel, S.E., 2005. Interleukin-13 augments transforming growth factor-beta 1-induced tissue inhibitor of metalloproteinase-1 expression in primary human airway fibroblasts. Am. J. Physiol., Cell Physiol. 288, C435-C442.

Zucker, S., Pei, D.Q., Cao, J., Lopez-Otin, C, 2003. Membrane type-matrix metalloproteinases (MT-MMP). Cell Surf. Proteases 54, 1-74.

Zuo, F.R., Kaminski, N., Eugui, E., Allard, J., Yakhini, Z., Ben Dor, A., Lollini, L., Morris, D., Kim, Y., DeLustro, B., Sheppard, D., Pardo, A., Selman, M., Heller, R.A., 2002. Gene expression analysis reveals matrilysin as a key regulator of pulmonary fibrosis in mice and humans. Proc. Natl. Acad. Sci. U. S. A. 99, 6292-6297. 